\title{
Pengaruh Model Pembelajaran Missouri Mathematics Project Dan Kecerdasan Matematis Logis Terhadap Hasil Belajar Matematika
}

\author{
Hindun Hanifah ${ }^{*}$, Khamidah Al'Izzaiyah ${ }^{2}$ \\ 1IAIN Salatiga, Salatiga, Indonesia \\ 2IAIN Salatiga, Salatiga, Indonesia \\ *Corresponding author: hindunhanifah6@gmail.com
}

\begin{abstract}
The goal of this reaseach is to determine the effect of the MMP model on mathematics learning outcomes, to determine the effect of intelligence logical mathematics to class student's mathematics learning outcomes, and to find out the significant effect between MMP models and logical mathematics on mathematics learning outcomes. This reseach is a type of quasi-experimental research with kuantitative approach with sistem random sampling. sample is taken by twenty person every class experiment and control.The data accumulation by test and processed by statistik non parametrik with uji kruskal Wallis H. After the aplication of the MMP model, it is known that there are differences in learning outcomes in the aplication MMP models is bettet than direc models. There are difference in learning outcomes based on logical mathematical intelligence. Students who have higger and medium based on logical mathematical intelligence are better than students who have lower based on logical mathematical intelligence. There is a significant interaction between the aplication of MMP model's and logical mathematical intellegence on learning outcomes, that in each category of logical mathematical intelligence, the mathematic learning outcomes the are subjected to the MMP model are better than the mathematic learning outcomes of students who are subjected to the direct model.
\end{abstract}

Keywords: logical mathematics; mathematic learning outcomes; missouri mathematics project (mmp) model

\section{ABSTRAK}

Penelitian ini bertujuan untuk mengetahui pengaruh model MPP terhadap hasil belajar siswa, untuk mengetahui pengaruh kecerdasan matematis logis terhadap hasil belajar siswa dan untuk mengetahui pengaruh model MMP dan kecerdasan matematis logis terhadap hasil belajar siswa. Jenis penelitian ini adalah quasi eksperimen dengan pendekatan kuantitatif. Populasi penelitian ini adalah seluruh siswa kelas V MI Tarbiyatul Banin dengan teknik pengambilan sample secara sample random sampling. Sample diambil masing-masing sebanyak 20 orang dari kelas eksperimen maupun kelas kontrol. Pengumpulan data diperoleh dari instrumen tes. Teknik analisis data menggunakan statistik non parametrik yaitu uji kruskal Wallis $\mathrm{H}$. Setelah penerapan model pembelajaran diperoleh hasil belajar siswa yang dikenai model MMP lebih baik dibandingkan dengan model langsung. Terdapat perbedaan hasil belajar siswa pada setiap tingkatan kecerdasan matematis logis. Siswa dengan kecerdasan matematis logis tinggi dan sedang memiliki hasil belajar yang lebih baik dibandingkan yang memiliki kecerdasan matematis logis rendah. Terdapat interaksi yang signifikan antara penerapan model MMP dan kecerdasan matematis logis terhadap hasil belajar siswa sehingga pada setiap kategori kecerdasan matematis logis, hasil belajar siswa yang dikenai model MMP lebih baik dibandingkan dengan hasil belajar siswa yang dikenai model langsung.

Kata Kunci: hasil belajar; kecerdasan matematis logis; model missouri mathematics project (mmp)

\section{PENDAHULUAN}

Matematika adalah pengetahuan terstruktur yang membahas tentang suatu sifat atau teori-teori yang dibuktikan secara deduktif berdasarkan unsur-unsur yang dapat didefinisikan maupun tidak berdasarkan sifat-sifat, aksioma, maupun teori kebenaran. Matematika merupakan pelajaran yang berisi tentang simbol-simbol dari berbagai gagasan menggunakan definisi-definisi yang cermat, akurat dan jelas. Matematika juga dikatakan pelajaran yang mengandung seni, karena di dalamnya terdapat keruntutan, keharmonisan dan keindahan. 
Matematika merupakan pelajaran yang penting karena dapat menjadi tonggak kemajuan ilmu pengetahuan dan teknologi. Nahdi (2018) menyatakan bahwa mengingat begitu pentingnya matematika maka mata pelajaran ini menjadi salah satu ilmu dasar sebagai mata pelajaran yang wajib diajarkan mulai tingkat pendidikan dasar sampai perguruan tinggi. Depdiknas menyatakan bahwa penguasaan dan penciptaan teknologi masa depan diperlukan penguasaan matematika sejak dini karena matematika bertujuan mengarahkan siswa mengembangkan kemampuan berpikir kritis, objektif dan memiliki sikap terbuka untuk memecahkan permasalahan. Yonanda (2017) mengemukakan dalam matematika, setiap konsep yang abstrak yang baru di matematika perlu segera diberi penguatan, agar mengendap dan bertahan lama dalam memori siswa sehingga akan melekat dalam pola pikir dan pola tindakannya. Untuk keperluan inilah, maka diperlukan adanya pembelajaran melalui perbuatan dan pengertian, tidak hanya sekedarhafalan atau mengingat fakta saja, karenahal ini akan mudah dilupakan siswa.

Pemahaman konsep dalam memahami pelajaran matematika sangat penting dimiliki setiap siswa. Menurut Febriyanto, dkk (2018) mengatakan bahwa pemahaman konsep matematis sangat penting karena ketika siswa paham akan suatu konsep, maka siswa akan mampu mengingat pelajaran matematika yang telah dipelajarinya dalam jangka waktu yang panjang. Namun, tidak semua siswa memiliki pemahaman yang sama dalam memahami setiap materi yang diajarkan pada mata pelajaran matematika. Hal tersebut dikarenakan setiap anak memiliki tingkat kecerdasan yang berbeda-beda dalam memahami matematika. Kecerdasan yang berperan penting dalam memahami matematika adalah kecerdasan matematis logis.

Kecerdasan matematis logis adalah kemampuan yang dimiliki seseorang dalam mengelola angka secara efektif untuk mendesain serta menghubungkan berbagai hal secara logis melalui percobaan-percobaan, mengerjakan teka teki dan menjawab pertanyaan secara logis dan masuk akal. Kecerdasaan matematis logis memiliki peranan yang sangat besar terhadap kemampuan matematika siswa terutama siswa di Indonesia, karena siswa di Indonesia masih memiliki kemampuan memahami mata pelajaran matematika dalam kategori rendah. Hal tersebut sesuai dengan hasil data pada Performance in Science, Reading and Mathematics (PISA) pada tahun 2015 tentang hasil rata-rata (mean) matematika, Indonesia menduduki peringkat ke-62 dari 70 negara dengan mean 386. Data tersebut menunjukkan bahwa kualitas matematika siswa di Indonesia masih rendah sehingga perlu diadakan peninjauan ulang untuk meningkatkan minat dan kemampuan matematika siswa.

Memahami pelajaran matematika merupakan salah satu kewajiban siswa yang harus bisa diajarkan guru dalam kegiatan pembelajaran. Salah satu cara yang bisa dilakukan guru untuk membantu memahami mata pelajaran matematika adalah menerapkan suatu model pembelajaran yang tepat yaitu model pembelajaran Missouri Mathematics Project (MMP). Missouri Mathematics Project (MMP) adalah sebuah model pembelajaran terstruktur yang terdiri atas review, pengembangan, kerja kelompok, tugas mandiri dan penugasan. Model MMP menyediakan kesempatan bagi siswa dan guru dalam kegiatan pembelajaran yang proaktif. Pada model pembelajaran ini guru bertindak sebagai fasilitator, sedangkan siswa bisa belajar secara aktif dengan cara bertukar pikiran, berdiskusi serta berlatih mengemukakan pendapat untuk menyelesaikan masalah. 
Penerapan model pembelajaran yang tepat mampu memudahkan siswa memahami materi yang diajarkan guru sehingga akan berdampak pada perolehan hasil belajar yang baik. Hasil belajar merupakan suatu bentuk kompetensi dan kemampuan siswa yang dapat diukut melalui performance siswa. Tingkah laku tersebut dapat diukur untuk menggambarkan indikator hasil belajar yang meliputi kegiatan mengidentifikasi, menyebutkan, menyusun, menjelaskan, mengatur dan membedakan. Hasil belajar tersebut merupakan suatu tindakan evaluasi yang dapat mengungkapkan aspek proses berpikir (cognitive domain) yang dapat mengungkap aspek kejiwaan lainnya, yaitu aspek nilai atau sikap (affective domain) dan juga aspek keterampilan (psychomotor domain) yang melekat pada diri setiap individu siswa.

Berdasarkan masalah-masalah yang sudah dipaparkan di atas maka penelitian ini memiliki tujuan untuk mengetahui pengaruh model pembelajaran missouri mathematics project (MMP) terhadap hasil belajar siswa, mengetahui pengaruh kecerdasan matematis logis terhadap hasil belajar siswa, serta untuk mengetahui pengaruh penerapan model model pembelajaran missouri mathematics project (MMP) dan kecerdasan matematis logis terhadap hasil belajar siswa pada mata pelajaran matematika yang akan bermanfaat sebagai acuan dalam kegiatan pembelajaran utuk menerapkan model pembelajaran yang bervariatif dan tepat pada masing-masing kegiatan pembelajaran sehingga akan diperoleh hasil belajar maksimal oleh masing-masing siswa.

\section{Metode Penelitian}

Jenis penelitian yang digunakan dalam penelitian ini menggunakan metode quasi eksperimen atau metode penelitian semu. Quasi experimen merupakan penelitian yang bertujuan untuk memperoleh informasi yang diperoleh dengan eksperimen yang tidak memungkinkan untuk mengontrol dan/atau memanipulasi semua variabel yang relavan. Penggunaan metode quasi eksperiment melibatkan dua kelompok, yaitu kelompok eksperimen dan kelompok kontrol. Pada penelitian ini, kelompok eksperimen diberikan perlakuan dengan menggunakan model pembelajaran MMP, sedangkan kelompok kontrol diberi perlakuan dengan menggunakan model pembelajaran langsung yang merupakan model yang digunakan guru dalam proses pembelajaran. Desain yang digunakan adalah design factorial. Design factorial yaitu desain penelitian dengan memperhatikan kemungkinan adanya variabel moderator yang mempengaruhi perlakuan (variabel independent) terhadap hasil (variabel dependen). ${ }^{\mathrm{i}}$

Tabel 1. Design Factorial

\begin{tabular}{|c|c|c|c|c|}
\hline \multicolumn{2}{|c|}{ Vaktor Variabel Independen } & \multicolumn{3}{|c|}{ Kecerdasan Matematis Logis (B) } \\
\hline & & Tinggi $\left(b_{1}\right)$ & Sedang $\left(b_{2}\right)$ & Rendah $\left(b_{3}\right)$ \\
\hline \multirow{2}{*}{$\begin{array}{c}\text { Model } \\
\text { Pembelajaran } \\
\text { (A) }\end{array}$} & Model MMP $\left(\mathrm{a}_{1}\right)$ & $a_{1} b_{1}$ & $a_{1} b_{2}$ & $a_{1} b_{3}$ \\
\hline & $\begin{array}{c}\text { Model Langsung } \\
\left(\mathrm{a}_{2}\right)\end{array}$ & $a_{2} b_{1}$ & $a_{2} b_{2}$ & $a_{2} b_{3}$ \\
\hline
\end{tabular}

Penelitian ini menggunakan pendekatan kuantitatf yaitu pendekatan penelitian yang bekerja pada angka berbentuk bilangan untuk dianalisis menggunakan rumus statistik dalam menjawab hipotesisi penelitian secara khusus. Instrumen yang digunakan dalam 
penelitian ini adalah tes pilihan ganda untuk mengukur kecerdasan matematis logis siswa dan hasil belajar siswa. Analisis data instrumen yang dilakukan dengan statistik non parametrik dengan uji kruskal wallis.

\section{Hasil dan Pembahasan}

\section{Uji Normalitas}

Penelitian ini dilaksanakan dengan subjek penelitian kelas V di MI Tarbiyatul. Berdasarkan hasil uji coba antara kelas eksperimen dan kelas kontrol maka diperoleh data normalitas pada Tabel 2 dan Tabel 3

Tabel 2. Hasil Output Uji Normalitas kelas eksperimen dan kelas kontrol

\begin{tabular}{llc}
\hline \multirow{3}{*}{ Hasil } & \multicolumn{1}{c}{ Value } & Kolmogorov- Smirnov (Sig.) \\
\cline { 2 - 3 } & Model MMP &. $\mathbf{2 0 0}$ \\
& Model Langsung & .200 \\
Matematis Logis Tinggi &. $\mathbf{1 2 0}$ \\
& Matematis Logis Sedang & .000 \\
& Matematis Logis Rendah & .001 \\
\hline
\end{tabular}

Berdasarkan tabel 2 terdapat data yang tidak normal yaitu pada kecerdasan matematis logis sedang dengan $P_{\text {value }}<$ a yaitu $P_{\text {value }}=0.00<0,05$ sehingga $H_{0}$ ditolak dan data berdistribusi tidak normal dan pada kecerdasan matematis logis rendah diperoleh $P_{\text {value }}<a$ yaitu $P_{\text {value }}=0.01<0,05$ sehingga $H_{0}$ ditolak dan data berdistribusi tidak normal, maka langkah selanjutnya dilakukan transformasi data dengan menggunakan Lg10.

Hasil normalitas pada data yang sudah ditransformasi dari hasil ulangan harian materi sifat-sifat bangun datar dan bangun ruang serta data hasil kecerdasan matematis logis siswa antara kelas eksperimen dengan kelas kontrol dapat dilihat pada Tabel 3.

Tabel 3. Hasil Output Uji Normalitas pada data transformasi kelas eksperimen dan kelas kontrol dengan Lg10

\begin{tabular}{llc}
\hline & \multicolumn{1}{c}{ Value } & Kolmogorov- Smirnov (Sig.) \\
\cline { 2 - 3 } Hasil & Model MMP &. $\mathbf{2 0 0}$ \\
& Model Langsung & .051 \\
& Matematis Logis Tinggi &. $\mathbf{0 7 4}$ \\
& Matematis Logis Sedang & .000 \\
& Matematis Logis Rendah & .001 \\
\hline
\end{tabular}

Berdasarkan Tabel 3 maka diperoleh hasil uji normalitas dari data setelah transformasi yaitu terdapat dua data yang berdistribusi tidak normal yaitu pada tingkatan kecerdasan matematis logis sedang diperoleh $P_{\text {value }}<$ a yaitu $P_{\text {value }}=0.00<0,05$ sehingga $H_{0}$ ditolak dan data berdistribusi tidak normal pada kecerdasan matematis logis rendah diperoleh $P_{\text {value }}<a$ yaitu $P_{\text {value }}=0.01<0,05$ sehingga $H_{0}$ ditolak dan data berdistribusi tidak normal. Sedangkan, kelas yang dikenai model MMP berdistribusi normal karena $P_{\text {value }}=0,200>0,05$ dan kelas yang dikenai model langsung berdistribusi normal karena $P_{\text {value }}=0,051>0,05$. Selanjutnya, Siswa dengan kecerdasan matematis logis tinggi berdistribusi normal karena $P_{\text {value }}=$ $0,074>0,05$. 


\section{Uji Homogenitas}

Adapun hasil uji homogenitas data antara kelas kontrol dengan kelas eksperimen pada model pembelajaran di kelas eksperimen dan kelas kontrol dapat dilihat pada Tabel 4.

Tabel 4. Hasil Output Uji Homogenitas Kelas eksperimen dan kelas kontrol pada Model Pembelajaran

\begin{tabular}{cc}
\hline \multicolumn{2}{c}{ Model Pembelajaran } \\
\hline Levene Statistic & Sig. \\
.894 & .350 \\
\hline
\end{tabular}

Berdasarkan Tabel 4 dapat diketahui bahwa $P_{\text {value }}>$ a yaitu $P_{\text {value }}=0.350>0,05$ sehingga $H_{0}$ diterima dan data Homogen pada penerapan model pembelajaran MMP dan model pembelajaran langsung.

Adapun hasil uji homogenitas data antara kelas eksperimen dengan kelas kontrol pada kecerdasan matematis logis dapat dilihat pada Tabel 5.

Tabel 5. Hasil Output Uji Homogenitas Kelas eksperimen dan kelas kontrol pada Kecerdasan Matematis Logis

\begin{tabular}{cc}
\hline \multicolumn{2}{c}{ Kecerdasan Matematis Logis } \\
\hline Levene Statistic & Sig. \\
.878 & .355 \\
\hline
\end{tabular}

Berdasarkan Tabel 5 dapat diketahui bahwa $P_{\text {value }}>$ a yaitu $P_{\text {value }}=0.355>0,05$ sehingga $H_{0}$ diterima dan data Homogen pada tingkatan kecerdasan matematis logis di kelas eksperimen dan kelas kontrol.

Berdasarkan Tabel 4 dan 5 dapat diketahui bahwa $P_{\text {value }}>$ a yaitu untuk model pembelajaran $P_{\text {value }}=0,350>0,05$ dan $P_{\text {value }}=0,355>0,05$ pada kecerdasan matematis logis antara kelas eksperimen dan kelas kontrol. Hal ini menunjukkan bahwa kedua kelas tersebut memenuhi kriteria $P_{\text {value }}>$ a sehingga $H_{0}$ diterima. Hal tersebut menunjukkan bahwa data kelas eksperimen dan kelas kontrol berasal dari variansi yang sama (homogen).

\section{Hasil Uji Coba}

Hasil Uji coba yang dilaksanakan di kelas eksperimen dan kelas kontrol diperoleh data yang dapat dilihat pada Tabel 6 .

Tabel 6. Data hasil penelitian yang dikenai model pembelajaran dan kecerdasan matematis logis.

\begin{tabular}{cccccc}
\hline $\begin{array}{c}\text { Model Pembelajaran } \\
(\mathbf{a})\end{array}$ & $\begin{array}{c}\text { Kecerdasan Matematis Logis } \\
\text { Tinggi } \\
\left(\boldsymbol{b}_{\mathbf{1}}\right)\end{array}$ & $\begin{array}{c}(\mathbf{b}) \\
\text { Sedang } \\
\left(\boldsymbol{b}_{\mathbf{2}}\right)\end{array}$ & $\begin{array}{c}\text { Rendah } \\
\left(\boldsymbol{b}_{\mathbf{3}}\right)\end{array}$ & Rerata Marginal \\
\hline Model MMP & $\mathbf{N}$ & 6 & 9 & 5 & 80,25 \\
$\left(\boldsymbol{a}_{\mathbf{1}}\right)$ & $\sum \mathbf{X}$ & 555 & 705 & 345 & \\
& $\overline{\boldsymbol{X}}$ & 92.5 & 78,33 & 69 & \\
Model & $\mathbf{N}$ & 5 & 5 & 10 & 74 \\
Langsung $\left(\boldsymbol{a}_{\mathbf{2}}\right)$ & $\sum \mathbf{X}$ & 450 & 385 & 645 & \\
& $\overline{\boldsymbol{X}}$ & 88 & 77 & 64,5 & \\
Rerata Marginal & 91,36 & 77,85 & 66 & \\
\hline
\end{tabular}


Selanjutnya, Setelah dilakukan uji normalitas dan uji homogenitas variansi sebagai syarat uji analisis variansi maka diketahui bahwa terdapat data yang berdistribusi tidak normal yaitu pada kecerdasan matematis logis sedang dan kecerdasan matematis logis rendah, namun variansi populasi siswa adalah sama (homogen). Oleh karena terdapat sampel yang tidak normal maka uji hipotesis penelitian tidak bisa menggunakan statistik parametrik. Akibatnya, digunakan uji statistik non parametrik dengan uji Kruskal Wallis H.

Adapun hasil pengujian statistik non parametrik dengan uji Kruskal Wallis H dapat dilihat pada Tabel 7.

Tabel 7. Hasil Output Pengujian Statistik nonparametris dengan uji Kruskal Wallis H

$\begin{array}{cc}\text { Model } & \text { Kecerdasan Matematis } \\ \text { Pembelajaran } & \text { Logis }\end{array}$

Asymp. Significant

.042

.048

Berdasarkan Tabel 7 maka dapat diketahui bahwa $P_{\text {value }}<$ a pada penerapan model pembelajaran yaitu $P_{\text {value }}=0,042<0,05$ dan pada kecerdasn matematis logis yaitu $P_{\text {value }}=$ $0,048<0,05$. Untuk mengetahui pengaruh antara model pembelajaran MMP dan kecerdasan matematis logis terhadap hasil belajar dalam setiap variabel dapat dijelaskan sebagai berikut,

Berdasarkan uji statistik non parametrik dengan uji Kruskal Wallis $\mathrm{H}$ pada Tabel 7 diketahui bahwa $P_{\text {value }}=0,042<0,05$ sehingga $H_{0}$ Ditolak, akibatnya terdapat perbedaan hasil belajar yang signifikan antara siswa yang dikenai model MMP dengan siswa yang dikenai model pembelajaran langsung. Berdasarkan uji statistik non parametrik dengan uji Kruskal Wallis $H$ pada Tabel 7 diketahui bahwa $P_{\text {value }}=0,048<0,05$ sehingga $H_{0}$ Ditolak, akibatnya terdapat perbedaan hasil belajar yang signifikan pada tingkatan kecerdasan matematis logis di kelas eksperimen dan kelas kontrol. Untuk mengetahui perbedaan pada tiap-tiap tingkat kecerdasan matematis logis siswa maka dilakukan uji lanjut yaitu dengan uji post hoc dengan menggunakan uji mann whitney.

Hasil pengujian post hoc dengan menggunakan uji mann whitney antara kecerdasan matematis logis tinggi dengan kecerdasan matematis logis sedang dapat dilihat pada Tabel 8

Tabel 8. Hasil Uji Post Hoc dengan Uji Mann Whitney antara Kecerdasan Matematis Logis Tinggi sengan Kecerdasan Matematis Logis Sedang

\section{Kecerdasan Matematis Logis}

Tinggi dan Sedang

\section{Asymp. Significant}

.000

Berdasarkan Tabel 8 maka dapat diketahui bahwa $P_{\text {value }}<$ a dengan tingkat signifikansi 0,05 pada perbandingan antara tingkat kecerdasan matematis logis tinggi dengan kecerdasan matematis logis sedang yaitu $P_{\text {value }}=0,000<0,05$ sehingga $H_{0}$ Ditolak. Adapun hasil pengujian post hoc dengan menggunakan uji mann whitney antara kecerdasan matematis logis tinggi dengan kecerdasan matematis logis rendah dapat dilihat pada Tabel 9. 
Tabel 9. Hasil Uji Post Hoc dengan Uji Mann Whitney antara Kecerdasan Matematis Logis Tinggi dengan Kecerdasan Matematis Logis Rendah

\title{
Kecerdasan Matematis Logis \\ Tinggi dan Rendah
}

\author{
Asymp. Significant
}

.000

Berdasarkan Tabel 9 maka dapat diketahui bahwa $P_{\text {value }}<$ a dengan tingkat signifikansi 0,05 pada perbandingan antara tingkat kecerdasan matematis logis tinggi dengan kecerdasan matematis logis rendah yaitu $P_{\text {value }}=0,000<0,05$ sehingga $H_{0}$ Ditolak.

Hasil pengujian post hoc dengan menggunakan uji mann whitney antara kecerdasan matematis logis sedang dengan kecerdasan matematis logis rendah dapat dilihat pada Tabel 10

Tabel 10. Hasil Uji Post Hoc dengan Uji Mann Whitney antara Kecerdasan Matematis Logis Sedang dengan Kecerdasan Matematis Logis Rendah

\section{Kecerdasan Matematis Logis \\ Sedang dan Rendah}

\section{Asymp. Significant}

.000

Berdasarkan 10 maka dapat diketahui bahwa $P_{\text {value }}<$ a dengan tingkat signifikansi 0,05 pada perbandingan antara tingkat kecerdasan matematis logis sedang dengan kecerdasan matematis logis rendah yaitu $P_{\text {value }}=0,000<0,05$ sehingga $H_{0}$ Ditolak. Berdasarkan Tabel 8, Tabel 9 dan Tabel 10 maka dapat diketahui bahwa $P_{\text {value }}<$ a dengan tingkat signifikansi 0,05 pada perbandingan antara tingkat kecerdasan matematis logis tinggi, sedang dan rendah, artinya ada perbedaan hasil belajar yang diperoleh siswa dengan tingkat kecerdasan matematis logis tinggi, sedang dan rendah.

Berdasarkan uji analisis data dengan menggunakan uji SPSS Statistik non parametris (uji kruskal wallis $\mathrm{H}$ ) dapat di lihat pada tabel 11.

Tabel 11. Hasil Output Interaksi Model Pembelajaran dan Kecerdasan Matematis Logis pada Uji Kruskal Wallis H

\section{Kecerdasan Matematis Logis \\ Sedang dan Rendah}

\section{Asymp. Significant}

.000

Berdasarkan Tabel 11 maka diketahui bahwa $P_{\text {value }}=0,000<0,05$ sehingga $H_{0}$ Ditolak. Akibatnya, terdapat interaksi yang signifikan antara penerapan model pembelajaran (MMP) dan kecerdasan matematis logis terhadap hasil belajar siswa.

Terdapat beberapa faktor yang menjadi pendukung dalam setiap proses belajar mengajar terutama belajar matematika. Faktor-faktor tersebut diantaranya penggunaan model pembelajaran dan kecerdasan matematis logis yang dimiliki siswa. Model pemebelajaran merupakan hal yang penting dalam kegiatan belajar mengajar. Penerapan model pembelajaran MMP berpengaruh terhadap hasil belajar siswa. Pada pelaksanaan model MMP guru bertugas sebagai fasilitator sedangkan siswa aktif dalam kegiatan 
pembelajaran dengan demikian siswa bisa belajar dengan mengeksplor kemampuan yang dimiliki serta bisa mengakses pelajaran dari berbagai sumber yang berdampak pada hasil belajar yang baik dibanding dengan siswa yang diterapkan model pembelajaran langsung.

Kecerdasan matematis logis sangat berpengaruh terhadap hasil belajar matematika siswa, siswa yang memiliki kecerdasan matematis logis tinggi memiliki hasil belajar matematika lebih baik dibandingkan dengan siswa yang memiliki kecerdasan matematis logis sedang dan rendah, siswa yang memiliki kecerdasan matematis logis sedang memiliki hasil belajar matematika yang lebih baik dibandingkan dengan siswa yang memiliki kecerdasan matematis logis rendah.

Penerapan model pembelajaran MMP dan kecerdasan matematis logis siswa pada setiap kategori kecerdasan berpengaruh terhadap hasil belajar matematika siswa. Siswa yang memiliki kecerdasan matematis logis tinggi dan diberi perlakuan model MMP memiliki hasil belajar yang lebih baik dibandingkan siswa yang diberi perlakuan model MMP dengan kecerdasan matematis logis sedang dan rendah. Begitu pula siswa yang memiliki kecerdasan matematis logis sedang dan diberi perlakuan model MMP memiliki hasil belajar yang lebih baik dibandingkan siswa yang diberi perlakuan model MMP dengan kecerdasan matematis logis rendah.

\section{Kesimpulan}

Berdasarkan hasil penelitian, analisis data dan pembahasan, maka diperoleh simpulan bahwa terdapat perbedaan hasil belajar matematika siswa pada penerapan model pembelajaran. Siswa yeng dikenai model MMP memiliki hasil belajar lebih baik dibandingkan siswa yang dikenai model pembelajaran langsung. Terdapat perbedaan hasil belajar matematika dalam tingkat kecerdasan matematis logis. Siswa yang memiliki keceradasan matematis logis tinggi memiliki hasil belajar yang lebih baik dibandingkan dengan siswa yang memiliki kecerdasan matematis logis sedang dan rendah. Siswa yang memiliki kecerdasan matematis logis sedang memiliki hasil belajar yang lebih baik dibandingkan dengan siswa dengan tingkat kecerdasan matematis logis rendah. Denga demikian, maka kecerdasan matematis logis berpengaruh terhadap hasil belajar siswa. Terdapat interaksi yang signifikan antara model pembelajaran Missouri Mathematics Project (MMP) dan kecerdasan matematis logis terhadap hasil belajar siswa. Hal tersebut dapat diketahui bahwa: pada setiap kategori kecerdasan matematis logis, siswa yang dikenai model pembelajaran MMP memiliki hasil belajar yang lebih baik dibandingkan dengan siswa yang dikenai model pembelajaran langsung, pada setiap penerapan model pembelajaran baik model MMP maupun model pembelajaran langsung, siswa dengan tingkat kecerdasan matematis logis tinggi memiliki hasil belajar yang lebih baik dibandingkan dengan siswa dengan tingkat kecerdasan matematis logis sedang dan rendah, siswa dengan tingkat kecerdasan matematis logis sedang memiliki hasil belajar yang lebih baik dibandingkan dengan siswa dengan tingkat kecerdasan matematis logis rendah. 


\section{Daftar Pustaka}

Febriyanto, B. Haryanti, Y.D. Komalasari, O. (2018). Peningkatan Pemahaman Konsep Matematıs Melaluı Penggunaan Media Kantong Bergambar Pada Materı Perkalian bilangan Di kelas II Sekolah Dasar. Jurnal Cakrawala Pendas Vol.4 No.2 Hal. 32-44.

Jelisaveta, S. (2016). Logical/Mathematical Intelligence in Teaching English as a second Language, International Converance of Teaching and Learning English as an additional Language, GlobELT 2016, 14-17 April, Procedia - Social and Behavioral Sciences 232(2016) 75-82, Turkey: Elsevier, p. 76

Lukad, V, Perdana, S, Budi, T S. (2016). Faktor-Faktor yang Mempengaruhi Hasil Belajar Siswa pada Pembelajaran Praktik Kelistrikan Otomotif SMK di Kota Yogyakarta. Jurnal Pendidikan Vokasi. Volume 6. No. 1. Februari 2016(111-120) p-ISSN: 2088-286. eISSN :2476-9401. Yogyakarta: ADGVI

Masrukhin. (2017). Metodologi Penelitian Kuantitatif. Kudus: Mibarda Publishing dan Media Ilmu Press

Nahdi, D.S. (2018). Eksperımentası Model Problem Based Learnıng Dan Model Guıded Discovery Learnıng Terhadap Kemampuan Pemecahan Masalah Matematıs Ditınjau Darı Self Efficacy Siswa. Jurnal Cakrawala Pendas Vol. 4 No.1. Hal. 50-56.

Purnamasari, Y. (2014). Pengaruh Model Pembelajaran Kooperatif Tipe Teams Games Tournament (Tgt) terhadap Kemandirian Belajar dan Peningkatan Kemampuan Penalaran dan Koneksi Matematik Siswa SMPN 1 Kota Tasikmalaya. Jurnal Pendidikan dan Keguruan Vol. 1 No. 1

Sugiyono. (2016). Metodologi Penelitian Pendidikan (Pendekatan Kuantitatif, Kualitatif, dan RED). Bandung: Alfabeta

Tombokan, J.R dan Selpius, K. (2016). Pembelajaran Matematika Dasar Bagi Anak Berkesulitan Belajar. Yogyakarta: Ar-Ruzz Media

Widyawati, N. (2017). Applying Missouri Mathematics Project Model in Enhancing Math Learning Outcomes, Internasional Journal of Managerial and Research (IJMSR). Volume 5. Issue, January 2017, PP15-18, ISSN 2349-0330 Print E ISSN 2349-0349 (Online). Surabaya: Sekolah Tinggi Ilmu Administrasi \& Manajemen Kepelabuhan Barunawati Surabaya, Indonesia.

Yonanda, D.A. (2017). Peningkatan Hasil Belajar Melalui Media Penggaris Rapitung. Jurnal Cakrawala Pendas Vol. 3 No.2. Hal. 64-71. 